\title{
鋼のコールドハビング用潤滑剤と各種鋼の 変形抵抗についで
}

\section{多賀谷正義 ${ }^{* *}$ 田村今 男***}

Masayoshi Tagaya and Imao Tamura : On the Lubricants and the Formability of Steels for Cold-Hubbing. A method for producing steel-dies by cold-hubbing has been recently developed. In this method, some inmortant problems remain unsolved on lubricants and tools, because steels have a high resistance to forming. In this report, the results of investigation on the effects of coatings and lubricants are described and also the results on the hubbing depths are compared and discussed for several steels, using a hardened W-Cr tool steel and a sintered carbide alloy as the hub materials. The lubricating properties were shown by the frictional force per unit contact area in the steady state of hubbing operation. Manganese phosphate was the most excellent as conting on the work steel. Molybdenum disulphide, stearate of divalent metals and wax such as stearil-alcohol were effective as the lubricants by co-operating with suitable coatings. The resistance to forming in plain carbon steels increased linearly with the carbon content. but in alloy steels it was higher than in plain carbon steels of the same carbon content. The commercially pure iron made by L.D. converter method had very low resistance to forming, and this material is to be noticed as the excellent cold-forming material. Even the high-resistance materials to forming, such as tool steels in annealed state, could be hubbed more than $40 \mathrm{~mm}$ in depth in one stroke. In such a case, however, the hub materials that can endure the pressure not less than $450 \mathrm{~kg} / \mathrm{mm}^{2}$ must be used.

(Received July 7,1962 )

\section{I. 緒}

コールドハビング(Cold Hubbing) によつて，各種の金 型を製作する方法が盛ん用いられるようになつてきた。

** 大阪大学工学部 (Faculty of Engineering, Osaka University, Osaka)
従来のごとき彫刻法では高価であり，長時間を要し需要に 応じきれないためである。しかし鋼の変形抵抗が大きいた

****大阪大学産業科学研究所 (The Institute of Scientific and Industrial Research, Osaka University, Osaka)

* 1961 年 4 月㧊よび 1962 年 4 月本会東京大会に発表 
めに，すべての型材についてハビングを行ならことは見在 な持困難で，軟鋼が主として用いられている，そのため用 途が限定され，プラスチックやゴム，ガラスなどの成形用 型を作つているにすぎない。この場合においても，どのよ らな鋼が最も適しているかを知らなければならないと同時 に，变形抵抗の大きい特殊工具鋼，ダイス鋼の金属成形用 型もハビングで簡単に製作出来れば型に関する多くの問題 を解決することが出来る。

そのためには，このような極王に耐える工具の強度と潤 滑剂が最も大きな要因であるといら見地から種々な㵎骬剤 の润滑作用について研究すると同時に，種々な鋼材を選ん で，ぞの程度加工出来るものかを検討し，工具についても 簡単な考察を行なつた，ハビングばかりでなく，鋼の冷間 盕性成型法は多くの長所をもち，現在注目をあびている加 工法であるが，これらのすべての加工法付しても何らか の示唆を与えるものと考える.

\section{II. 実 験 方 法}

ブランク材（被加工材）としては Table 1 に示寸鋼材を 完全焼なましして用いたが，潤滑凨の研究には主として酸 素上吹転炉によつて溶製された工業用純鉄を用いた。形状 は直径 $47 \mathrm{~mm}$ ，長さ $75 \mathrm{~mm}$ の円柱で，ホルダー・リング

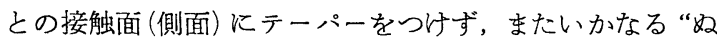

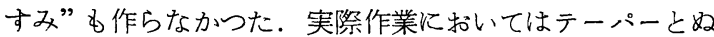
すみを適当化つるのであるが，これらは実験条什を複雑 にし，特にぬすみをつけることは，潤滑郕を研究する目的 には润滑面積を少なくし，あるいは材料の全体的な流動 を少なくするすので，ふさわしくない，もちろんテーパー や奴みをつけることにより，ハビングは非常に容易にな
よつて最初の $20 \mathrm{t}$ を予借荷重とし，その後の圧力一圧入深 さ曲線を求めた。この際ラムの移動距離を測定したが，体

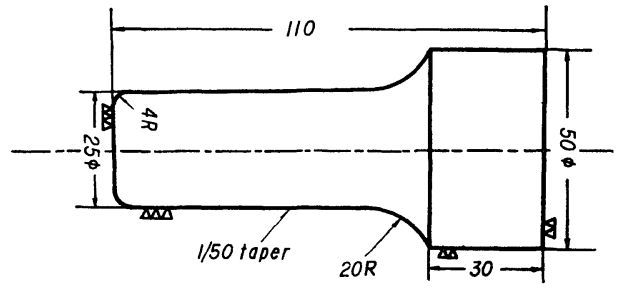

Fig.1 Dimensions of hub used.

積不変として計算した実際の区入深さで示した。本実験の 場合实際の圧入深さはラム移動距離の 1.39 倍であつた. 圧入速度は $0.01 \mathrm{~mm} / \mathrm{sec}$ で最高荷重は SKS 3 ハブの場合 $245 \mathrm{~kg} / \mathrm{mm}^{2}$, 超硬合金の場合 $450 \mathrm{~kg} / \mathrm{mm}^{2}$ とした。

\section{III. 潤 滑 皮 膜}

潤滑皮膜は潤滑剤の補助作用をすると同時に焼付防止に 効果があり，鋼の冷間加工には必須のるのである．従来伸 線などでは燐酸塩皮膜，とくに燐酸亜鉛系皮膜が多く用い られ，またアルカリ処理，石灰付けなどは古くから用いら れ銅，鉛，錫などの皮膜も材質に応じて使用されている(1) $\sim(5)$.

ブランク材として L.D. 法によつて溶製された工業用純 鉄を用い，種々な潤滑皮膜を被覆して，その上に潤滑剤と してステアリン酸鉛を塗布した場合，圧力ー圧入深曲線は Fig.2 打よびFig.3 のようになる。曲線は三つの段階か ら成つて打り，大略 $120 \sim 130 \mathrm{~kg} / \mathrm{mm}$ で定常圧入段階(6) に入っている．潤滑作用がすぐれているほぞこの段階が長 く，乙か子傾斜がゆるやかで圧力上升が少ない。

Table 1 Chemical composition and hardness of steels used.

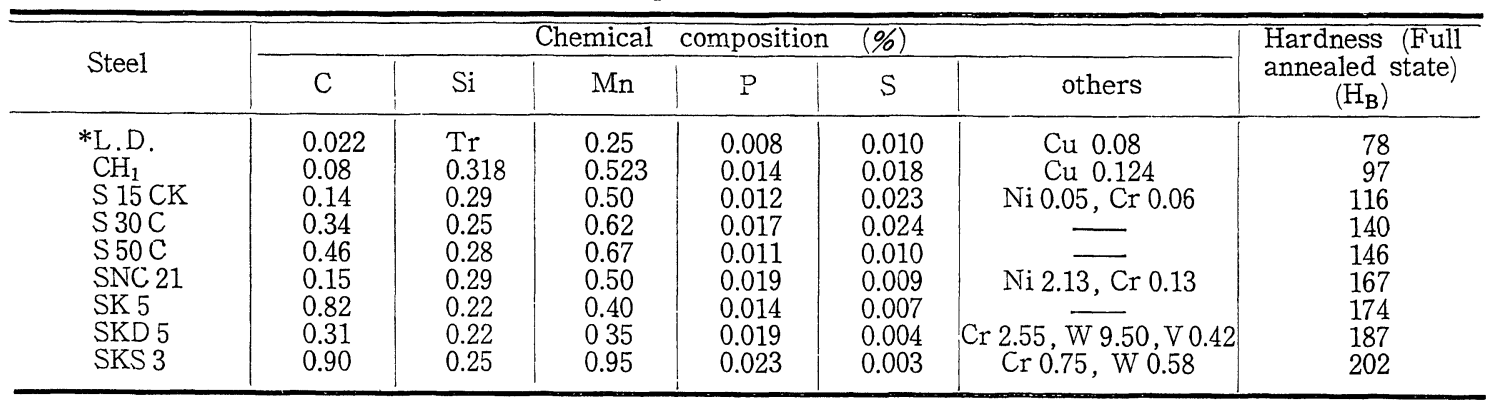

* A steel nuade by L. D. converter.

る、それ故本実鈳の場合，テーパーやぬすみをつけた場合 よりも苛酷な条件で実験したわけである．Fig.1にハブの 形状を示寸.值径 $25 \mathrm{~mm}$ で 1/50 のテーパーをつけてある. このテーパーは王入後のハブの抜取りを容易にするための もので，これも実験条件を複雑にするわけであるが，実験 遂行上やむをえないもので，最低限のテーパーとした，八 ブの材質としてはSKS 3 の焼入れ材 (RC 62) と超硬合金の 2 種を用いた。ブランク材とハブの直径比は $47: 25$ で减 面率は約 25\%である。

殴入方法は Sack und Kiesselbach 製 2500 tプレスに
これらの図からわかるように，燐酸塩皮膜の秀れている ことは明瞭であるが，燐酸マンガン系皮膜がとくにすぐれ

(1) W.Leng, K.H. Treptow : Stahl u.Eisen, 76 (1956), 1107.

(2) W.Leng, K.H.Treptow : Stahl u.Eisen, 72 (1952), 1207.

(3) K.H.Treptow: Stah1 u.Eisen, 73 (1953), 666.

(4) Fritz Schwier: Stahl u.Eisen, 73 (1953),925.

(5) E. C. Tompson, J. B. Carroll, E. Bevit: J. Iron Steel Inst., 173 (1953), 36 .

（6）久能木：日本機械学会論文集，22 (1956)，No. 118, $418,424,437$. 
ていることは注目すべきことである．燐酸踾鉛系皮膜にス

無いときは焼付が著しく固体皮膜があってはじめてすぐれ テアリン酸亜鉛の潤滑剂を用いた場合，兆鉛の相互作用に

た性能を発揮する，テフロン，ナイロンを被覆したものは

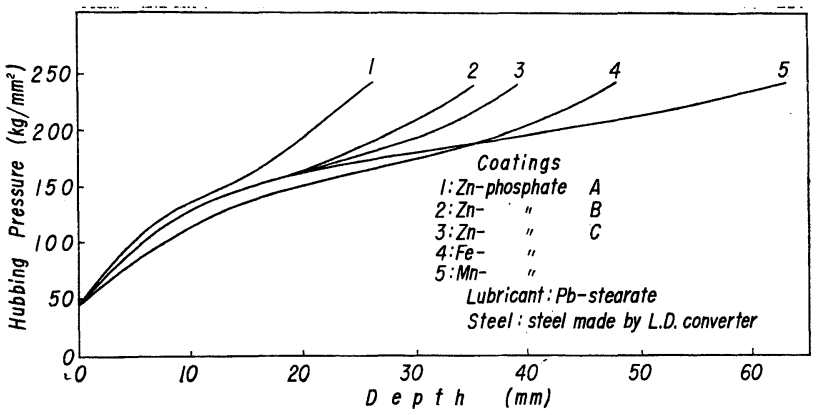

Fig.2 Comparison of various phosphate as coatings. 引吊を括こす。な扰これらの場合は，下地皮膜を使 用しなかつた。

Fig.5 は金属石檢の場合で，鉛，愐鉛などの 2 価 金属塩がすぐれていることを示している．Fig.6は その他の種々の潤滑剤について示しているが，ステ アリルアルコールのような蠟がすぐれていることは 注目すべきことである.な拉.6亿は下地皮膜と して最もすぐれている燐酸マンガン系皮膜を施し て，潤滑剤としてモリコートGとステアリン酸鉛を 用いた場合の曲線も付記して㐫る。これらは本実験

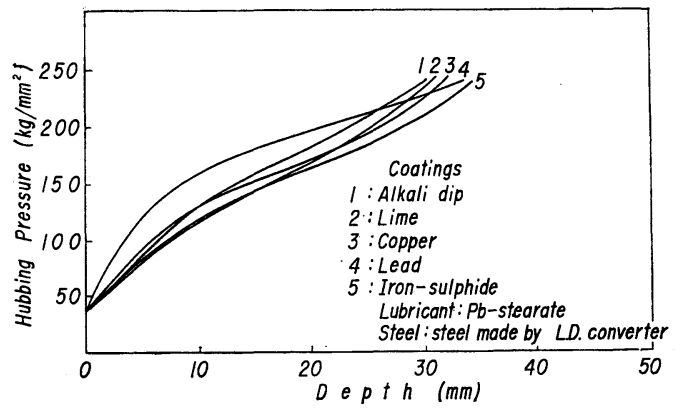

Fig.3 Comparison of various coatings. よつてか潤滑作用が少し改善されるが顕著ではなかつた。

\section{IV. 潤 滑 剂}

このような高圧下の潤滑には主として固体潤滑剤が使用

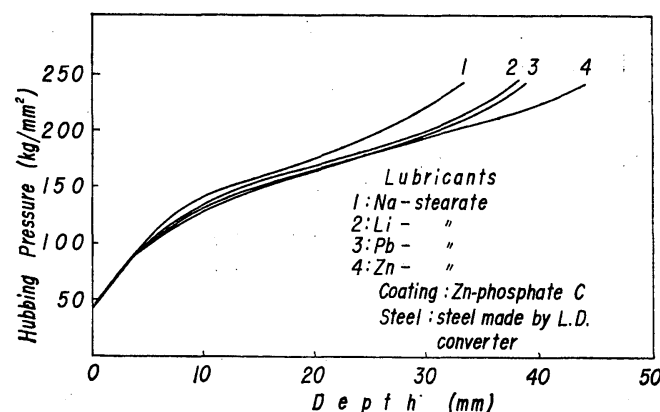

Fig. 5 Comparison of various lubricants (2), various stearate of metals.

によつて得られた最もよい潤滑条件で実験したものであ

る. $245 \mathrm{~kg} / \mathrm{mm}^{2}$ までの圧力で $60 \mathrm{~mm}$ 以上の圧入が 1 回で できることは特筆すべきことである。 される(1)〜(5)(7)(8)。本研究においては, 液体, 固体, 有機，無機のきわめて多くの潤滑剂について実験し た、いま，潤滑皮膜としての燐酸西鉛系皮膜を施し た場合について代表的なものを示すと，Fig.4は二 硫化モリブデン，コロイダルグラフ アイト，テフロ ン被覆の場合を示す，二硫化モリブデンの秀れてい ることが明瞭に現われている，二硫化モリブデンの 中でもその粒の細かさなどによつて異なり，モリコ 一トの場合ペースト状の Gが最もすぐれ，粒の細か いマイクロファインはよくない。このように二硫化 モリブデンは潤滑性がすぐれているが，潤滑皮膜の

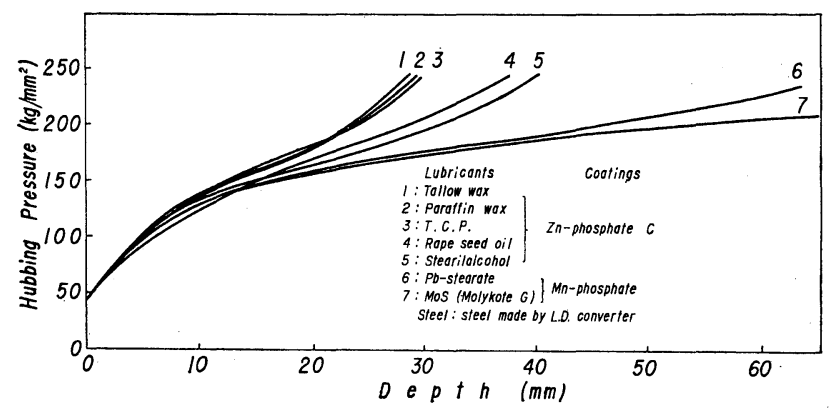

Fig.6 Comparison of various lubricants (3), several lubricants and the most excellent lubrications in this work.

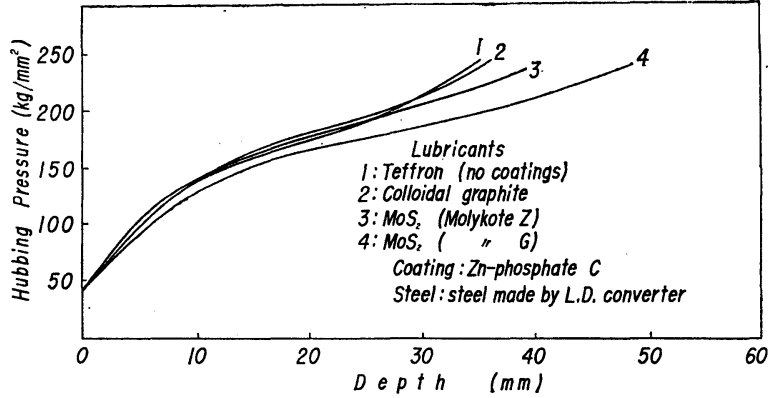

Fig.4 Comparison of various lubricants (1), teffron graphite and molybdenum disulphide.

(7) A.J.Stock: Metal Progr., 76(1959), No.3, 147 A (ダイジェスト).
以上の实験から潤滑剤としては二硫化モリブデン 2 価 の金属石瞼，ステアリルアルコールのような蠟がすぐれ ていることがわかる。しかし潤滑剤の効果は圧力－王入 深曲線の第 1 段階ではほとんど認めることができず，第 2 段階の定常圧入段階ではじめて大きな効果の相違が現 われてくる．第1段階はほとえど鋼の変形抵抗のみに関 係するようである．それ故 $10 \mathrm{~mm}$ 程度の玨入のときは ほとんど潤滑剤の効用はわからない。

( 8 ) J.Gaensheimer : Metal Progr., 77 (1960) ,No.6,200 (ダイジェスト)，执よび Preprint of the Seminar on Friction, Lubrication and Wear, Lucerne, Switzerland, Sept. 18, 1959. 


\section{V. 各種鋼材の変形抵抗}

以上は主に L.D. 鋼についての実験であるが, 鋼種が変 り，それに応じて変形抵抗が大となると定常圧入段階は高 い王力のところで扔こる. SKS 3 のハブでは $300 \mathrm{~kg} / \mathrm{mm}^{2}$ 以上の圧力では破壊の危険があるので $250 \mathrm{~kg} / \mathrm{mm}^{2}$ 以下で 実験した. Fig.7 は燐酸マンガン系皮膜とステアリン酸鉛 を潤滑剤とし、て用いたときの圧力ー圧入深曲線である。ス テフリン酸亜鉛を潤滑郕にした場合も同様である.

曲線は三つの段階から成り立ち, 弾性変形, 降伏, 塑性 変形, 加工硬化を扣こすに従つて圧力が急増大する。 こ れが第 1 段階である。 そしてある程度圧入されると定常圧 入段階に達する. これが第 2 段階の比較的勾配のゆるやか

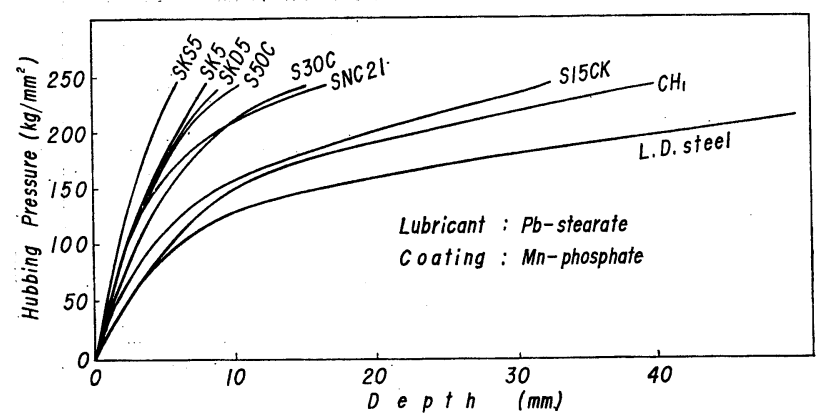

Fig.7 Work resistances for several steels using the hub of hardened SKS 3 tool steel.

な段階である. 定常圧入に入ると，摩擦の增加がなけれ ば，圧力の上䄯なしに圧入されるはずであるが，実際は摩 擦の增加のためほとん气゙直線的に上界する，潤滑膜が切れ て金属が相互に直接接触すると摩擦が著しく大となり，圧 力が急増大する．これが第 3 段階で，焼付きもこの段階 でおこる．それ故，これらの素材の変形抵抗は第 1 段階か ら定常圧入に入るときの臨界の圧力で示すことができる.

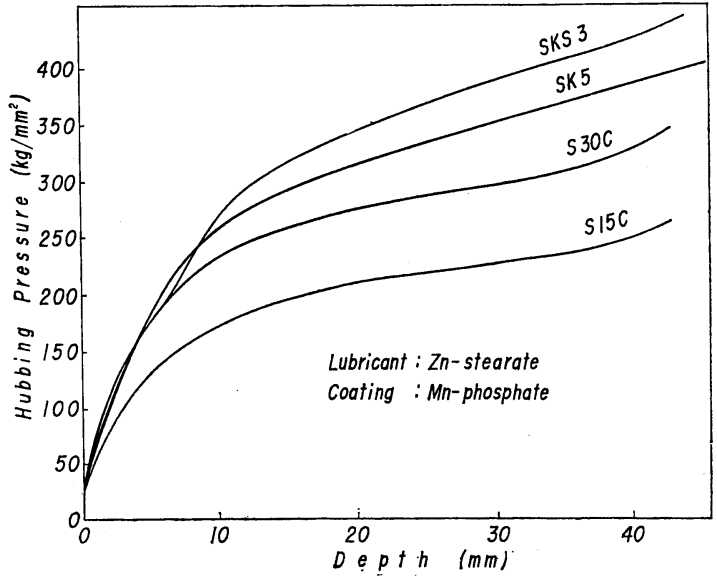

Fij.8 Work resistances for several steels using the hub of sintered carbide alloy.

Fig.7 によると, L.D. 鋼, $\mathrm{CH}_{1}, \mathrm{~S} 15 \mathrm{CK}, \mathrm{SNC} 21, \mathrm{~S} 30 \mathrm{C}$, S 50 C, SKD5, SK 5, SKS 3 の順に変形抵抗が大きくなつ ていることがわかる。しかし $245 \mathrm{~kg} / \mathrm{mm}^{2}$ までの圧力では L.D. 鋼, $\mathrm{CH}_{1}, \mathrm{~S} 15 \mathrm{CK}$ のよ 5 な変形抵扰の小さい軟鋼の
みしか定常圧入段階に達していない，

ここでL.D. 鋼は不純物が少なく純鉄に近いため変形抵 抗がきわめて小さいことは，当然のことであるけれどる特 筆すべきことであり，この種の冷間塑性加工用鋼として注 目すべきである. 約 $200 \mathrm{~kg} / \mathrm{mm}^{2}$ の 圧力で $60 \mathrm{~mm}$ 以上の 圧入を 1 回で成し遂げることができる.

超硬合金八ブを用いて $450 \mathrm{~kg} / \mathrm{mm}^{2}$ までの圧力をかけて 実験した結果は Fig.8 のよ5である。この図からわかる 上了に変形抵抗の大きい鋼に抬いては定常圧入に入る圧力 が高くなるが，定常圧入段階に㧊ける傾斜はほとんど同一 で，平行している. しかし定常圧入段階が高い圧力レベル になると幾分傾斜が急になるようである。すなわち定常圧 入段階では主として潤滑効果が大きな役割を果してい るようである，従つて潤滑効果をよくし，高圧に耐え る工具を用いれば工具鋼，合金工具鋼のような硬い， 変形抵抗の大きい材料でも完全にハビングすることが 可能であり，1回で $40 \mathrm{~mm}$ 以上の 圧入を成し遂げる ことができる。

\section{VI. 考察および結果の総括}

第 1 段階から定常圧入段階に入るときの臨界の圧 力, すなわち変形抵抗 $U_{p}$ は普通引張り強さの $3 \sim 5$

倍といわれている(9).この $U_{p}$ の值を上述の曲線から 求めることは正確を期し難いが，これを読み取つて炭素量 との関係として図示すると Fig.9のようになる.炭素鋼で は大略炭素量に従つて直線的に上昇する，合金鋼ではこの 直線で示されるよりも高く現われる，とくにダイス鋼にお いて著しい.ブリネル硬度との関係をとれば $\mathbf{F i g . 1 0 の よ ~}$ らになる，炭素鋼では一つの曲線の上に乗り，合金鋼では その曲線の下側に現われる．すなわち鋼材の変形抵抗は炭

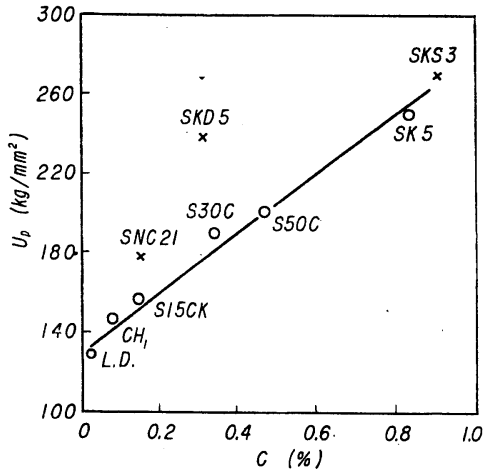

Fig.9 Relationship of forming resistance versus carbon content of various steels at annealed state.

素量とともに増大し，合金元素が存在するとさらに変形抵 抗を増す。

前述のように摩擦面に摩擦がないものと考えると, 定常 圧入段階に入れば，玨力の増加なしに压入されてゆくはず

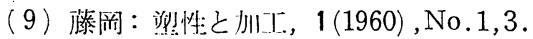


である。しかし実際にはほとんど直線的に玨力が増加して いる.そして潤滑阂の相違によつてこの段階に拈ける傾斜

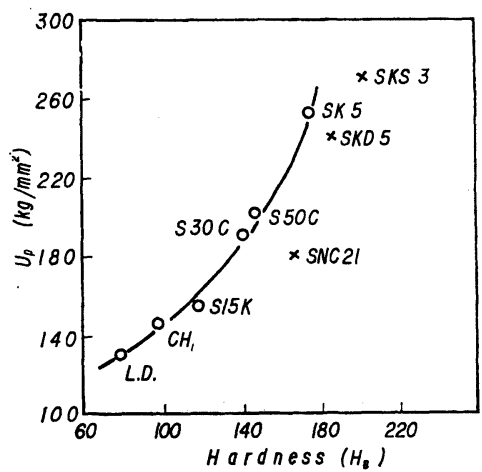

Fig.10 Relationship of forming resistance versus Brinell hardness of various steels at annealed state.

が違つている。これは明らかに圧入進行による摩擦面の增 大と潤滑効果の相違を示するのである。すぐれた潤滑剤を 用いれば定常王入段階に扣ける傾斜が小さく，この段階が 長く続き，烍付きの段階に達し難い，そして結果的には小 さい正力で深く王入できるわけである.

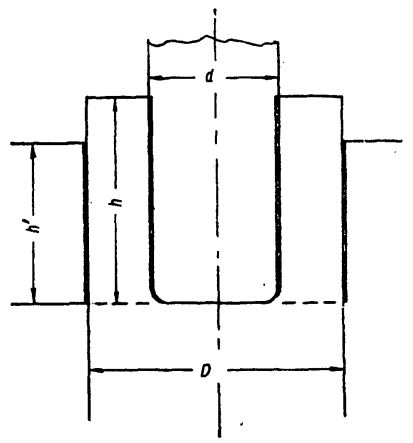

Fig.11 The contact area during hubbing.

このような旺入段階に 扣ける材料の流れおよび その組織については多く の研究がなされており(6) (9)〜(11), これらの結果を みると，仕入㭙に拈ける 界面の摩擦は Fig.11の 太線で示した部分で抗こ つているようである。压 入深さ $h$ のとさ摩擦面 積 $S_{h}$ は

$$
\begin{aligned}
S_{h} & =\pi d h+\pi D h^{\prime} \\
h & =D^{2} h^{\prime} /\left(D^{2}-d^{2}\right)
\end{aligned}
$$

となる，定常圧入段階において佰重が $\Delta p \mathrm{~kg}$ 上昇したとき $\Delta h \mathrm{~mm}$ だけ圧入されたものとすると，とのときの単位面 積当りの摩擦力の上年を $\eta \mathrm{kg} / \mathrm{mm}^{2}$ とすると,

$$
\eta=\Delta P / \pi\left\{d+\left(D^{2}-d^{2}\right) / D\right\} \cdot \Delta h
$$

で示される。クの值が小さいほど閏滑性能がよい.

$\eta の$ 値について，上記の L.D. 鋼での実験結果をまとめ ると，定常玨入段階に沶いて临滑皮膜に対しては Table 2 のようであり，潤滑剂については Table 3 のようである。 これらの表には $150 \mathrm{~kg} / \mathrm{mm}^{2}$ のときの生入深さ（定常殴入 段階に入つた初期) および SKS 3 八ブによる最高圧力 245 $\mathrm{kg} / \mathrm{mm}^{2}$ のときの最大圧入深さをも示している. $245 \mathrm{~kg} /$ $\mathrm{mm}^{2}$ においては，潤滑剂の種類によつてはすでに第 3 段 階に入り，焼付きを抗こしているすのあある.

（10）小川，竹内：精密機械, 14 (1958), No.12,669.

(11) 粟野, 山川, 伊藤：名古屋工技試報告, 5(1956), No.9,7 特よび 6(1957), No.5,9.
これらの表からわかるよ5に, 潤滑皮膜としてはマンガ ン系, 鉄系, 亜鉛系の燐酸塩皮膜, 硫化鉄, 鉛, 銅, 石灰,

Table 2 Comparison of lubricating properties for various coatings.

\begin{tabular}{l|c|c|c}
\hline \hline \multicolumn{1}{c|}{ Coatings. } & $\begin{array}{c}\text { Depth at } \\
150 \mathrm{~kg} / \mathrm{mm}^{2} \\
(\mathrm{~mm})\end{array}$ & $\begin{array}{c}\eta \\
\left(\mathrm{kg} / \mathrm{mm}^{2}\right)\end{array}$ & $\begin{array}{c}\text { Depth at } \\
245 \mathrm{~kg} / \mathrm{mm}^{2} \\
(\mathrm{~mm})\end{array}$ \\
\hline Zn-phosphate (A) & 16 & 7.7 & 39.2 \\
Mn-phosphate & 16 & 4.7 & 63.5 \\
Fe-phosphate & 19 & 7.1 & 48.2 \\
Zn-phosphate (B) & 13 & 15.5 & 26.2 \\
Zn-phosphate (C) & 16 & 7.8 & 35.4 \\
Copper & 15 & 11.6 & 32.5 \\
Iron-sulphide & 16 & 10.8 & 34.0 \\
Lead & -8 & 9.4 & 34.0 \\
Alhali dip & 12 & 12.0 & 30.3 \\
Lime & 17 & 16.3 & 31.4 \\
\hline
\end{tabular}

$\mathrm{Pb}$-stearate was always used as the lulricant. L.D. converter steel was used as the work material.

\begin{tabular}{|c|c|c|c|}
\hline Lubricants & $\left|\begin{array}{c}\text { Depth at } \\
150 \underset{\mathrm{kg} / \mathrm{mm}^{2}}{(\mathrm{~mm})}\end{array}\right|$ & $\begin{array}{c}\eta \\
\left(\mathrm{kg} / \mathrm{mm}^{2}\right)\end{array}$ & $\begin{array}{c}\text { Depth at } \\
245 \mathrm{~kg} / \mathrm{mm}^{2} \\
(\mathrm{~mm})\end{array}$ \\
\hline Rape-seed oil & 15 & 10.3 & 37.5 \\
\hline T.C.P. & 13 & 11.6 & 30.1 \\
\hline Paraffin wax & 13 & 11.3 & 29.7 \\
\hline Tallow wax & 13 & 13.5 & 29.0 \\
\hline Stearilalcohol & 15 & 8.6 & 40.1 \\
\hline Li-stearate & 14 & 8.6 & 38.2 \\
\hline $\mathrm{Na}$-stearate & 13 & 9.9 & 33.4 \\
\hline $\mathrm{Pb}$-stearate & 15 & 8.6 & 39.2 \\
\hline Zn-stearate & 14 & 7.7 & 44.1 \\
\hline Teffron & 13 & 9.6 & 35.3 \\
\hline $\mathrm{MoS}_{2}$ (Molykote G) & 14 & 5.7 & 48.4 \\
\hline $\mathrm{MoS}_{2}$ (Molykote Z) & 12 & 7.7 & 39.9 \\
\hline $\mathrm{PbO}$ & 12 & 11.6 & 29.2 \\
\hline $\mathrm{Pb}_{2} \mathrm{O}_{3}$ & 14 & 10.1 & 31.7 \\
\hline $\mathrm{Ba}(\mathrm{OH})_{2}$ & 12 & 12.5 & 27.5 \\
\hline $\mathrm{CaCO}_{3}$ & 9 & 11.4 & 25.8 \\
\hline Talc & 14 & 16.3 & 27.6 \\
\hline Waterglass & 12 & 10.8 & 31.7 \\
\hline Colloidal graphite & 12 & 9.0 & 35.1 \\
\hline${ }^{*} \mathrm{MoS}_{2}($ Molykote G) & 16 & 4.3 & $65.2^{* *}$ \\
\hline *Pb-stearate & 16 & 4.7 & 63.5 \\
\hline
\end{tabular}

Table 3 Comparison of lubricating properties for various lubricants.

Zn-phosphate was used as the coating.

L.D. converter steel was used as the work material.

* Mn-phosphate was used as the coating.

** The depth at $225 \mathrm{~kg} / \mathrm{mm}^{2}$.

アルカリの順に悪くなつており，燐酸マンガン系皮膜が恪 段とすぐれていることがわかる，潤滑剤ではモリコート $\mathrm{G}$, ステアリン酸亜鉛, モリコートZ, ステアリルアルコ 一ル，ステアリン酸鉛などがすぐれている．しかして燐酸 マンガン采皮膜を下地とし，これらのすぐれた澗滑剂を使 用すれば最高の潤滑効果をうることができる.

八ビングの加工条件は圧力がきわめて高く，速度が遅 い，そのため Stribeck の曲線から考えても，潤滑面に和 いて金属 - 金属接触を扣こしやすく, 潤滑は困難である. このような条件に扣いて閏滑效果をよくする潤滑剂として は, 液体潤滑剂による動水王的な潤滑 (Hydrodynamic Lubrication) では油膜強度が不十分で, どうしても固体潤 滑剂にたよらなければならない，Gaensheimer(8)によれ ば，固体潤滑剂がすぐれた潤滑効果を示すためには，固体 
潤滑㶡の剪断强度が小さくて，金属表面によくなじみ，金 属表面をよく覆つて金属一金属接触を防ぎ，しかも揱断強 度が小さくても潤滑の単位の磻は非常に强固で弾性に富 み，金属表面の突起部などによつて，潤滑膜が破られるこ とのないことが必要である。このような条件にあう固体潤 滑剂としては2硫化モリブデンやグラフフイトのよ5な 無機層状結晶化合物がーずれ，たと充ば 2 硫化モリブデン の境合, その結晶構造は S-Mo-S-S-Mo-Sというょ5に 層状に配列し，S-Mo の結合虫强国であるが，S-S 結合は 弱く，そのため結晶心少しの剪断応力によつてあ崩れる が，最後に残るS-Mo-S結合は非常に強国て，この単位結

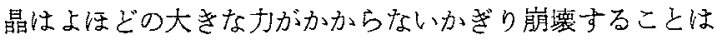
なく，強固な潤滑膜を形成する，しかも2 硫化主りブデン は比重が大きく緻密で，金属に対してよくなじむ，々れは Sが金属表面に吸着しやすいためである。ワックス，金属 石羷なども固体潤滑剂として広く使用され，これらは金属 表面に非常に強い吸着皮膜を作るためであると考えられて いる.

潤滑下地皮膜としての燐膘塩皮膜は，その表面の結晶棈 造が非堂に繳密で，潤滑剂の潤滑皮膜形成を容易にすると 同時にその湟滑皮膜の崩壊を防ぐといわ机ている，ハビン グのような荷酷な条件では，潤滑剤のみではいかに強固な 澗滑被膜です崩壊され，どうしても燐酸塩の下地皮膜を必 要とする．従来マンガン系扣よび鉄系燐酸塩皮膜は摩擦に よる引つかき減少するといわれて扣り，西鉛系は主とし て鋼の加工に使用されている．鋼の加工にも種々な方法が あるから，ハピングには引つかきを減少するマンガン系が すぐれているようである。また潤滑剂としては上記の理由

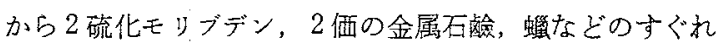
ていることがうなずかれるが，詳細についてはいはだ考察 する段階に到つていない。
VII，結言

鋼のコールドハビング用潤滑剂と，各種鋼材の変形抵抗 について研究を行なつた結果，潤滑皮膜としては燐酸、ン ガン系皮膜が最もすぐれていることがわかつた，潤滑剂と

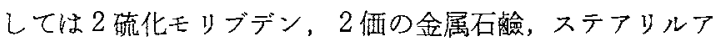
ルコールのよらな蠟がすぐれている。これらの潤滑剂の潤 滑性能を定常圧入段階にお外る単位接触面積あたりの摩擦 力をもつて量的に表示した，変形抵抗の大きい鋼材に和い ても，定常王入段栺に括ける傾斜は潤滑法が同一の場合に

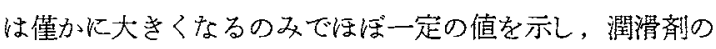
性能のみに関係する，乙か乙定常王入に達するまでの浅い 圧入のとさに潤滑剂の効果はほとんど認るられず，むつ ぱら鋼の変形抵抗のみに依存する。

変形抵抗は炭素量とともに菴線的に上㫒するが，合金鋼 はこの直線よりも䯩く現われる。便さとの関係をとると， 炭素鋼は一つの曲線で示されるが，合金銅はこの曲線の下 涀われる。すなわり炭素量が多い活ど変形抵抗は大き く，合金元素が多くなると一殿大となる。

上記の最良の潤滑法を用いた場合、軟鋼では $245 \mathrm{~kg} / \mathrm{mm}^{2}$ の压力で $60 \mathrm{~mm}$ 以上の 代入が 1 回で可能であり，とくに L.D. 鋼はきわ変形抵抗少なく，成形が容易で冷間塑 性加工用鋼材として注目すべきである。㞸菜工具鋼や合金 工具銊のよろな硬い材料でも一度に $40 \mathrm{~mm}$ 以上のハビン グが可能である.しかし $450 \mathrm{~kg} / \mathrm{mm}^{2}$ 以上の王力に耐える ハブを使用しなければならないので，今後工具材料の開発 が望委れる。

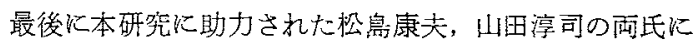
感謝する。またプレスの使用括よびその他の曤宜を与えら れた松下電器産業(株)中央研究所，材料を提供された日本 鋼管 (株)，(株) 日本鉄工所，超硬合金ハブを提供された住 友電気工業(株)，就よび閏滑剂を提供された菱東石湖(株)，

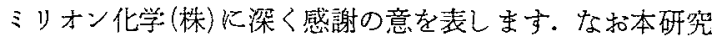
は昭和 36 年度 文部省科学試騟研究費によつて行なつたも のである。 